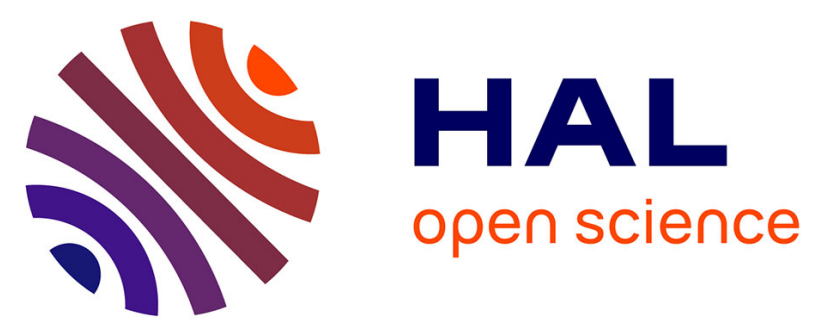

\title{
The Stability of Gahnite Doped with Chromium Pigments in Glazes from the French Manufacture of Sèvres
}

Louisiane Verger, Olivier Dargaud, Gwenaelle Rousse, Marine Cotte, Laurent Cormier

\section{To cite this version:}

Louisiane Verger, Olivier Dargaud, Gwenaelle Rousse, Marine Cotte, Laurent Cormier. The Stability of Gahnite Doped with Chromium Pigments in Glazes from the French Manufacture of Sèvres. Journal of the American Ceramic Society, 2016, 10.1111/jace.14452 . hal-01368522

\section{HAL Id: hal-01368522 \\ https://hal.sorbonne-universite.fr/hal-01368522}

Submitted on 19 Sep 2016

HAL is a multi-disciplinary open access archive for the deposit and dissemination of scientific research documents, whether they are published or not. The documents may come from teaching and research institutions in France or abroad, or from public or private research centers.
L'archive ouverte pluridisciplinaire HAL, est destinée au dépôt et à la diffusion de documents scientifiques de niveau recherche, publiés ou non, émanant des établissements d'enseignement et de recherche français ou étrangers, des laboratoires publics ou privés. 


\title{
The Stability of Gahnite Doped with Chromium pigments in
}

\section{Glazes from the French Manufacture of Sèvres}

Louisiane Verger ${ }^{1,2}$ Olivier Dargaud, ${ }^{2}$ Gwenaelle Rousse, ${ }^{3}$ Marine Cotte,,${ }^{4,5}$ Laurent Cormier ${ }^{1}$

1. Institut de Minéralogie, de Physique des Matériaux et de Cosmochimie (IMPMC), Sorbonne Universités, UPMC Univ Paris 06, CNRS UMR 7590, Museum National d'Histoire Naturelle, IRD UMR 206, 4 place Jussieu, F-75005 Paris, France

2. Cité de la céramique - Sèvres et Limoges, 2 Place de la Manufacture, 92310 Sèvres, France. www.sevresciteceramique.fr

3. Chimie du Solide et Energie, FRE 3677, Collège de France, 11 place Marcelin Berthelot, 75005 Paris, France

4. European Synchrotron Radiation Facility, 71 Avenue des Martyrs, 38300 Grenoble, France

5. Laboratoire d'Archéologie Moléculaire et Structurale, CNRS-UPMC, UMR 8220, 4 place Jussieu, 75005 Paris, France

\begin{abstract}
The French manufacture of Sèvres, famous for its production of fine porcelain artefacts, has been synthesizing pink pigments mainly composed of the spinel phase $\mathrm{ZnAl}_{2-\mathrm{x}} \mathrm{Cr}_{\mathrm{x}} \mathrm{O}_{4}$ with $x$ varying from 0.25 to 0.41 since the middle of the $19^{\text {th }}$ century. This kind of pigment is mixed with an uncolored frit to obtain decorations for porcelain artefacts. However, the pink color of
\end{abstract}


the pigment is altered in a particular uncolored frit and a brownish color appears. The mechanism of this color change was investigated. Observations under a scanning electron microscope revealed the formation of a phase rich in $\mathrm{Cr}$ resulting from reactions between the uncolored frit and the pigment during firing. X-Ray Diffraction combined with Rietveld refinements and X-Ray Absorption Near Edge Structure at the Cr K-edge measurements showed that the new formed phase belongs to the same spinel phase $\mathrm{ZnAl}_{2-\mathrm{x}} \mathrm{Cr}_{\mathrm{x}} \mathrm{O}_{4}$ than the pigment, but with a higher $\operatorname{Cr}$ content $x$. We showed that its formation and thus the stability of the pigment is driven by the $\mathrm{Al}$ content in the uncolored frit.

\section{Introduction}

Pink decorations on porcelain artefacts can be obtained using different kinds of pigments, such as cassiterite, ${ }^{1,2}$ malayaite, ${ }^{3-5}$ or spinel doped with chromium. ${ }^{6}$ Recently, several studies have focused on the spinel solid solution gahnite-zincochromite $\mathrm{ZnAl}_{2-\mathrm{x}} \mathrm{Cr}_{\mathrm{x}} \mathrm{O}_{4}$ due to its change in coloration with the chromium content. ${ }^{6-9}$ The introduction of a few ppm of chromium in the colorless gahnite $\mathrm{ZnAl}_{2} \mathrm{O}_{4}$ gives a pink coloration to the material. Due to its optical properties, this oxide can be used as a pigment for porcelain. The French manufacture of Sèvres, famous for its production of fine porcelain artefacts, ${ }^{10}$ has been synthesizing pigments composed of gahnite doped with chromium since the $19^{\text {th }}$ century. They have been extensively used to obtain salmon pink decoration on porcelain artefacts between the end of the $19^{\text {th }}$ century and the beginning of the $20^{\text {th }}$ century (Fig. 1). The detailed synthesis of Sèvres's pigments has been reported by D'Albis. ${ }^{10}$ Mixtures of these pigments with an uncolored frit are applied on the porcelain and fired at high temperature to form a glaze, i.e. a decorative glassy layer on the porcelain with a typical thickness between 100 and $500 \mu \mathrm{m}$. Two main compositions of uncolored frit are used at the manufacture of Sèvres depending on the chemical composition of the porcelain they are applied on: one is used only on a porcelain 
fired at $1380^{\circ} \mathrm{C}$, while the other one is used on a porcelain fired at lower temperature, $1280^{\circ} \mathrm{C}$. $\mathrm{ZnAl}_{2} \mathrm{O}_{4}: \mathrm{Cr}^{3+}$ type pigments are only used in the former to obtain pink decorations. In the second one, we observed an alteration of the pink color of the pigment: a brownish hue appears after the thermal treatment of the glaze.

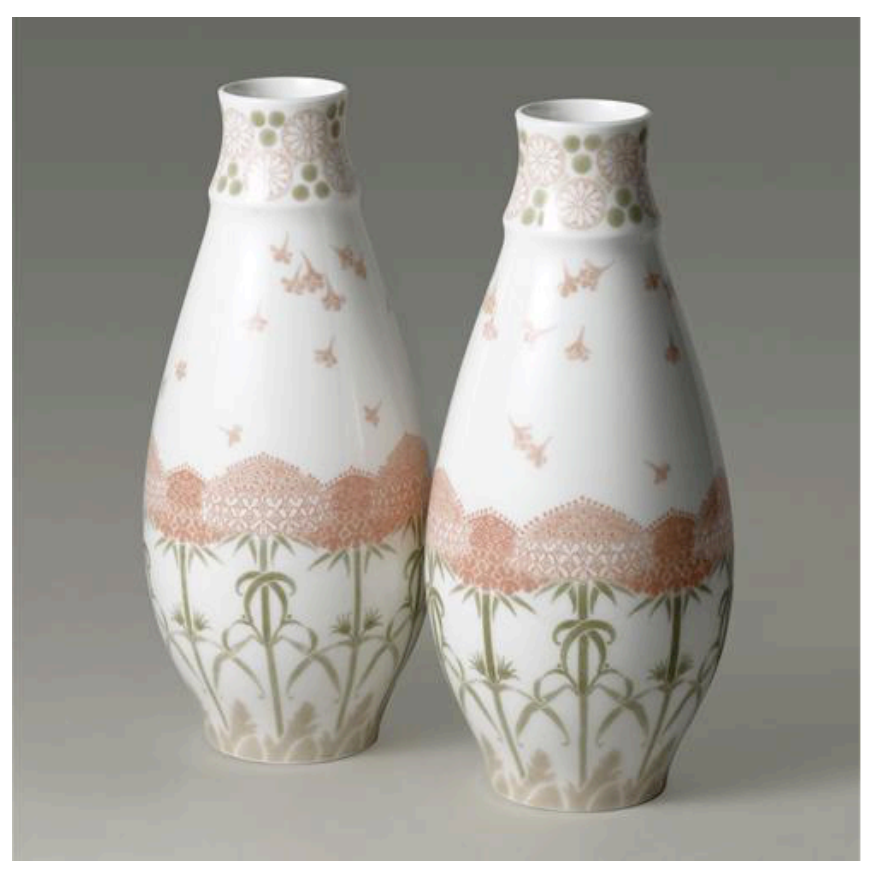

Fig. 1. Vase from Achères (1900), from the collection of the Cité de la céramique, ORMNGrand Palais. The pink colour is typical of $\mathrm{ZnAl}_{2} \mathrm{O}_{4}: \mathrm{Cr}^{3+}$ type pigment.

The coloring properties of a glaze are not only dependent on the crystal structure of the initial pigment, but also on possible reactions which can occur between the pigment and the uncolored frit during firing. ${ }^{11-13}$ The interaction of pigments with glazes was investigated in the literature on various systems such as $\mathrm{Fe}-\mathrm{Cr}$ corundum base pigments. ${ }^{14,15}$ However a complete study of the mechanism of dissolution of a spinel pigment in a particular frit or glaze has never been undertaken to our knowledge. 
We aim in this work at investigating by a multi-analytical approach the stability of $\mathrm{ZnAl}_{2} \mathrm{O}_{4}: \mathrm{Cr}^{3+}$ type pigment during firing processes. We were able to understand the mechanism of color changes observed, and to discuss the role of chromium and aluminium in the reactivity of spinel in silicate melts.

\section{Experimental procedure}

\section{(1) Sample preparation}

The palette of pigments used at Sèvres for porcelain decoration is composed of 138 references, indexed from 10001 to $10138 .{ }^{10}$ Their synthesis were developed at the laboratory of the manufacture between the middle of the $19^{\text {th }}$ century and the $20^{\text {th }}$ century. Four of them are composed of a phase belonging to $\mathrm{ZnAl}_{2-\mathrm{x}} \mathrm{Cr}_{\mathrm{x}} \mathrm{O}_{4}$ with $x$ varying from 0.25 to 0.41 . The pigment numbered 10045 was selected for this study because it is the most commonly used at the manufacture. It is synthesized from $\mathrm{ZnO}, \mathrm{Al}(\mathrm{OH})_{3}$ and $\mathrm{Cr}_{2} \mathrm{O}_{3}$ with the use of $\mathrm{NaNO}_{3}$ as a flux $(\mathrm{Zn}: \mathrm{Al}: \mathrm{Cr}: \mathrm{Na}=1.54: 1.61: 0.39: 0.42)$, and calcined at $1400^{\circ} \mathrm{C}$ without a plateau. Besides pigment 10045 , three compositions along the solid solutions $\mathrm{ZnAl}_{2-\mathrm{x}} \mathrm{Cr}_{\mathrm{x}} \mathrm{O}_{4}$ with $x=0.4,1.0$ and 1.4 were synthesized. Reagent-grade chemicals $\mathrm{ZnO}, \gamma-\mathrm{Al}_{2} \mathrm{O}_{3}$ and $\mathrm{Cr}_{2} \mathrm{O}_{3}$ were weighted in the right stoichiometric proportions, mixed, ground in an agate mortar with ethanol and calcined in a platinum crucible at $1400^{\circ} \mathrm{C}$ during 20 hours.

Glazes are obtained by mixing $0.5 \mathrm{~g}$ of the coloring agent (pigment 10045 from Sèvres or synthesized references) with $4.5 \mathrm{~g}$ of an uncolored crystallized frit named CI. The mixture is milled in a planetary agate mortar during 10 minutes at $300 \mathrm{rpm}$. This procedure was applied to each glaze in order to have a similar particle size distribution for each sample. The frit is composed of feldspar, kaolin, quartz and chalk in proportions specific to the porcelain of Sèvres. To assess the effect of the frit, the classical uncolored frit CI from Sèvres was 
modified by the addition of 0.20 or $0.45 \mathrm{~g}$ of $\alpha-\mathrm{Al}_{2} \mathrm{O}_{3}$ to $4.5 \mathrm{~g}$ of CI. Table 1 gives the chemical composition of the different frits CI, CIAl1 and CIAl2. The mixture of the pigment and the frit is painted on a round porcelain mount, which is then fired with the following heat treatment in use at the manufacture: $1000^{\circ} \mathrm{C}$ is reached in ten hours (linear heat-up ramp of $100^{\circ} \mathrm{C}$ per hour), then $1280^{\circ} \mathrm{C}$ is reached in $5 \mathrm{~h} 30$ (linear heat-up ramp of approximately $50.9^{\circ} \mathrm{C}$ per hour). Once $1280^{\circ} \mathrm{C}$ is reached, the kiln is either maintained at a plateau or immediately turned off and slowly cooled down to room temperature. The atmosphere of the kiln is not controlled for the preparation of this kind of decoration. The sample obtained with this procedure is called R-1280. To follow the evolution during firing, the kiln was also turned off at $1180,1200,1220,1240$ and $1260^{\circ} \mathrm{C}$ and the resulting samples are called R-1180, R-1200, R-1220, R-1240 and R-1260. Table 2 summarizes the name and characteristic of the different glazes obtained by varying the different parameters (temperature of firing, composition of the pigment or composition of the uncolored frit).

Table 1: Chemical composition in molar percentage of the uncolored frit CI from Sèvres and the two frits CIAl1 and CIAl2 modified by the addition of 0.2 and $0.45 \mathrm{~g}$ of $\alpha-\mathrm{Al}_{2} \mathrm{O}_{3}$ in $4.5 \mathrm{~g}$ of CI, respectively.

\begin{tabular}{lcccccccc}
\hline & $\mathrm{SiO}_{2}$ & $\mathrm{Al}_{2} \mathrm{O}_{3}$ & $\mathrm{CaO}$ & $\mathrm{K}_{2} \mathrm{O}$ & $\mathrm{Na}_{2} \mathrm{O}$ & $\mathrm{MgO}$ & $\mathrm{TiO}_{2}$ & $\mathrm{Fe}_{2} \mathrm{O}_{3}$ \\
& & & & & & & & \\
\hline CI & 74.36 & 8.53 & 12.04 & 2.46 & 2.36 & 0.07 & 0.09 & 0.09 \\
CIA11 & 72.34 & 11.02 & 11.71 & 2.39 & 2.30 & 0.07 & 0.09 & 0.08 \\
& & & & & & & & \\
CIA12 & 69.97 & 13.93 & 11.33 & 2.31 & 2.22 & 0.06 & 0.09 & 0.08 \\
\hline
\end{tabular}


Table 2: Summary of the different glazes prepared by mixing pigment and uncolored frit and obtained after the heating treatment (final temperature and plateau).

\begin{tabular}{|c|c|c|c|c|}
\hline Sample Name & Pigment & Uncolored frit & Final temperature $\left({ }^{\circ} \mathrm{C}\right)$ & Plateau (hours) \\
\hline R-1280 & 10045 & $\mathrm{CI}$ & 1280 & 0 \\
\hline R-1260 & 10045 & CI & 1260 & 0 \\
\hline $\mathrm{R} 1240$ & 10045 & CI & 1240 & 0 \\
\hline R-1220 & 10045 & CI & 1220 & 0 \\
\hline R-1200 & 10045 & $\mathrm{CI}$ & 1200 & 0 \\
\hline R-1180 & 10045 & CI & 1180 & 0 \\
\hline R-1350-10h & 10045 & CI & 1350 & 10 \\
\hline $\mathrm{R}-1280-5 \mathrm{~h}$ & 10045 & $\mathrm{CI}$ & 1280 & 5 \\
\hline $\mathrm{R}-1200-5 \mathrm{~h}$ & 10045 & CI & 1200 & 5 \\
\hline $\mathrm{R}-1160-5 \mathrm{~h}$ & 10045 & CI & 1160 & 5 \\
\hline $\mathrm{R}-\mathrm{AlCr04}$ & $\mathrm{ZnAl}_{1.6} \mathrm{Cr}_{0.4} \mathrm{O}_{4}$ & CI & 1280 & 0 \\
\hline $\mathrm{R}-\mathrm{AlCr} 10$ & $\mathrm{ZnAl}_{1.0} \mathrm{Cr}_{1.0} \mathrm{O}_{4}$ & $\mathrm{CI}$ & 1280 & 0 \\
\hline $\mathrm{R}-\mathrm{AlCr} 14$ & $\mathrm{ZnAl}_{0.6} \mathrm{Cr}_{1.4} \mathrm{O}_{4}$ & CI & 1280 & 0 \\
\hline R-CIAl1 & 10045 & CiAl1 & 1280 & 0 \\
\hline R-CIAl2 & 10045 & CIA12 & 1280 & 0 \\
\hline R-CIAl1-1350-10h & 10045 & CIAl1 & 1350 & 10 \\
\hline R-CIAl2-1350-10h & 10045 & CIA12 & 1350 & 10 \\
\hline
\end{tabular}

\section{(2) Analytical Methods}

X-ray diffraction (XRD) data were collected using a PANalytical X'Pert PRO diffractometer with $\mathrm{Cu} \mathrm{K} \alpha$ radiations $\left(\lambda_{\mathrm{Cu}, \mathrm{K} \alpha 1}=1.54056 \AA, \lambda_{\mathrm{Cu}, \mathrm{K} \alpha 2}=1.54439 \AA\right)$ operating under $40 \mathrm{kV}$ and 
40mA. XRD patterns for the pigment 10045 were measured on powered samples, between 5 and $130^{\circ}$, with a step of $0.008^{\circ} 2 \theta$ and a counting time of $25 \mathrm{~s} / \mathrm{step}$. XRD patterns were measured directly on the glazes without specific preparation, between 10 and $130^{\circ}$, with a step of $0.016^{\circ} 2 \theta$ and a counting time of $550 \mathrm{~s} / \mathrm{step}$. The lattice parameters of the different phases were determined using the Rietveld method, ${ }^{16}$ as implemented in the FullProf Suite program..$^{17}$

Diffuse reflectance spectra were measured using a Perkin Elmer Lambda 1050 spectrometer with an integrating sphere. The pigment 10045 was finely ground and the powder was deposited on a sample holder. The spectra were recorded between 4000 and $36000 \mathrm{~cm}^{-1}$ directly on the glaze surface, without specific preparation. The white reference was a perfectly flat tablet of $\mathrm{BaSO}_{4}$. Reflectance data were converted into absorption spectra using the Kubelka-Munk remission function $\mathrm{F}\left(\rho_{\infty}\right){ }^{18}$

Cross sections were cut from the porcelain shard with the glaze on the top. These fragments were embedded in a resin block, polished using diamond pastes down to $3 \mu \mathrm{m}$ and carbon coated. Scanning Electron Microscopy (SEM) analyses were conducted with a Zeiss Ultra55, with an acceleration voltage of $15 \mathrm{keV}$, a working distance of $7.5 \mathrm{~mm}$ and a backscattered electron detector, associated to an Energy Dispersive Spectroscopy (EDS) microprobe. Based on this analysis, areas of interest were selected for the X-ray absorption Near Edge Structure (XANES) measurements at the Cr K-edge.

X-ray fluorescence (XRF) maps and macro and micro XANES data at the $\mathrm{Cr} \mathrm{K}$-edge $(5989 \mathrm{eV})$ were collected on the ID21 beamline at ESRF (Grenoble, France). The powdered pigment 10045 was fixed on a thin film XRF tape and covered with ultralene film. The cross sections of the glazes were fixed directly on the sample holder. The incident beam was monochromatized using a $\mathrm{Si}(220)$ monochromator calibrated with a $\mathrm{Cr}$ metallic foil. The beam size on the powdered pigments was $200 \times 200 \mu \mathrm{m}^{2}$. To characterize the glaze, the beam 
was focused down to $0.2 \mathrm{x} 0.7 \mu \mathrm{m}^{2}$. $\mu$-XRF maps were acquired on areas of interest previously selected under the SEM. XRF spectra were batch fitted using the software PyMCA, ${ }^{19}$ used to generate elemental maps and identify points of interest for $\mu$-XANES measurements. XANES spectra were recorded in XRF mode between $5960 \mathrm{eV}$ and $6210 \mathrm{eV}$ with a step of $0.2 \mathrm{eV}$ and an accumulation time of $1 \mathrm{~s} / \mathrm{step}$. Five and ten scans were recorded for the powdered pigment 10045 and the regions of interest of the glazes, respectively. The scans were summed and the resulting spectrum was normalized using the software PyMCA.

\section{Results}

\section{(1) Crystalline nature of the pigment 10045}

In order to determine the crystalline phases present in the pigment 10045, a XRD investigation was carried out. Fig. 2 presents the XRD pattern of the pigment 10045 used for the glaze and its Rietveld refinement. The lattice parameter a of the phase $\mathrm{ZnAl}_{2-\mathrm{x}} \mathrm{Cr}_{\mathrm{x}} \mathrm{O}_{4}$ is linked with the chromium occupancy $x$ by the equation:

$a(\AA)=0.1215 x+8.086(\AA)$

derived from our previous XRD investigation on this solid solution. ${ }^{9}$ Both lattice parameter and chromium occupancy are fitted during the refinement and they are in good agreement. Since $a$ and $x$ are nicely correlated, we prefer to use the equation (1) to obtain $x$ from $a$. Two phases are found in the pigment 10045: a small amount of $\mathrm{ZnO}$ and a majority of $\mathrm{ZnAl}_{1.59} \mathrm{Cr}_{0.41} \mathrm{O}_{4}$. $\mathrm{ZnO}$ remains in 10045 probably because reagents are not used in stoichiometric proportion for the synthesis of this pigment. Indeed, the crystalline purity of the pigment is not necessarily looked for at Sèvres, but rather its coloring properties in a glaze. The small chromium content of the $\mathrm{ZnAl}_{2} \mathrm{O}_{4}: \mathrm{Cr}^{3+}$ gives a pink coloration to this pigment. 


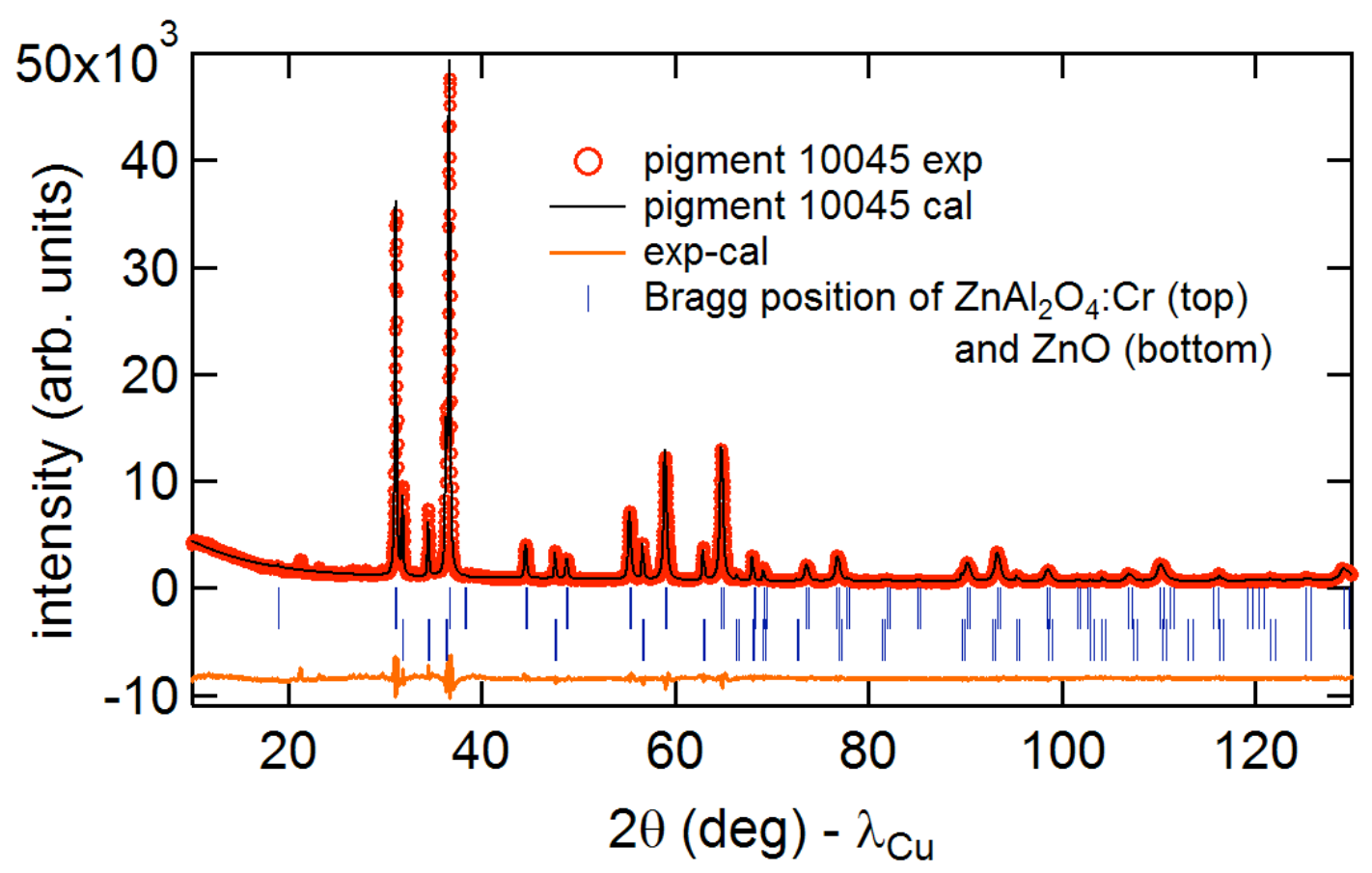

Fig. 2. Rietveld refinement of the pigment 10045 showing two phases: $\mathrm{ZnAl}_{1.59} \mathrm{Cr}_{0.41} \mathrm{O}_{4}$ and $\mathrm{ZnO}$. The red dots are the observed intensities, the black line is the calculated intensity. Blue vertical tick marks indicate Bragg positions in space group $F d \overline{3} m$ (top) for $\mathrm{ZnAl}_{1.59} \mathrm{Cr}_{0.41} \mathrm{O}_{4}$ and $\mathrm{Pb}_{3} m c$ (bottom) for $\mathrm{ZnO}$. The orange line plots the difference between observed and calculated intensities.

\section{(2) Evolution of the pigment in the glaze}

When the pink pigment 10045 is used in a particular frit CI, the glaze becomes brown after the thermal treatment (see pictures of the samples in Fig. 3). The pigment and the glaze were characterized by optical absorption spectroscopy. Fig. 3 shows the remission function $\mathrm{F}\left(\mathrm{Q}_{\infty}\right)$ of the initial pigment 10045 and from the glaze R-1280. The high absorption of pigment 10045 in the near UV region can be explained by the presence of $\mathrm{ZnO}$, a semi-conductor compound, with a gap energy located at $26600 \mathrm{~cm}^{-1}$ in the visible region. The spectra show 
two main intense absorption bands, typical of trivalent chromium, $\mathrm{Cr}^{3+}$, in a slightly distorted octahedral symmetry. ${ }^{9,20,21}$ The bands position varies between the initial pigment and the glaze, from about 18350 to $17890 \mathrm{~cm}^{-1}\left(v_{l}\right)$ and from about 26250 to $24330 \mathrm{~cm}^{-1}\left(v_{2}\right)$. The shift in energy of the absorption bands is due to the diminution of the crystal field parameter. It indicates that the pigment 10045 reacts during the thermal treatment, which results in the simultaneous color modification.

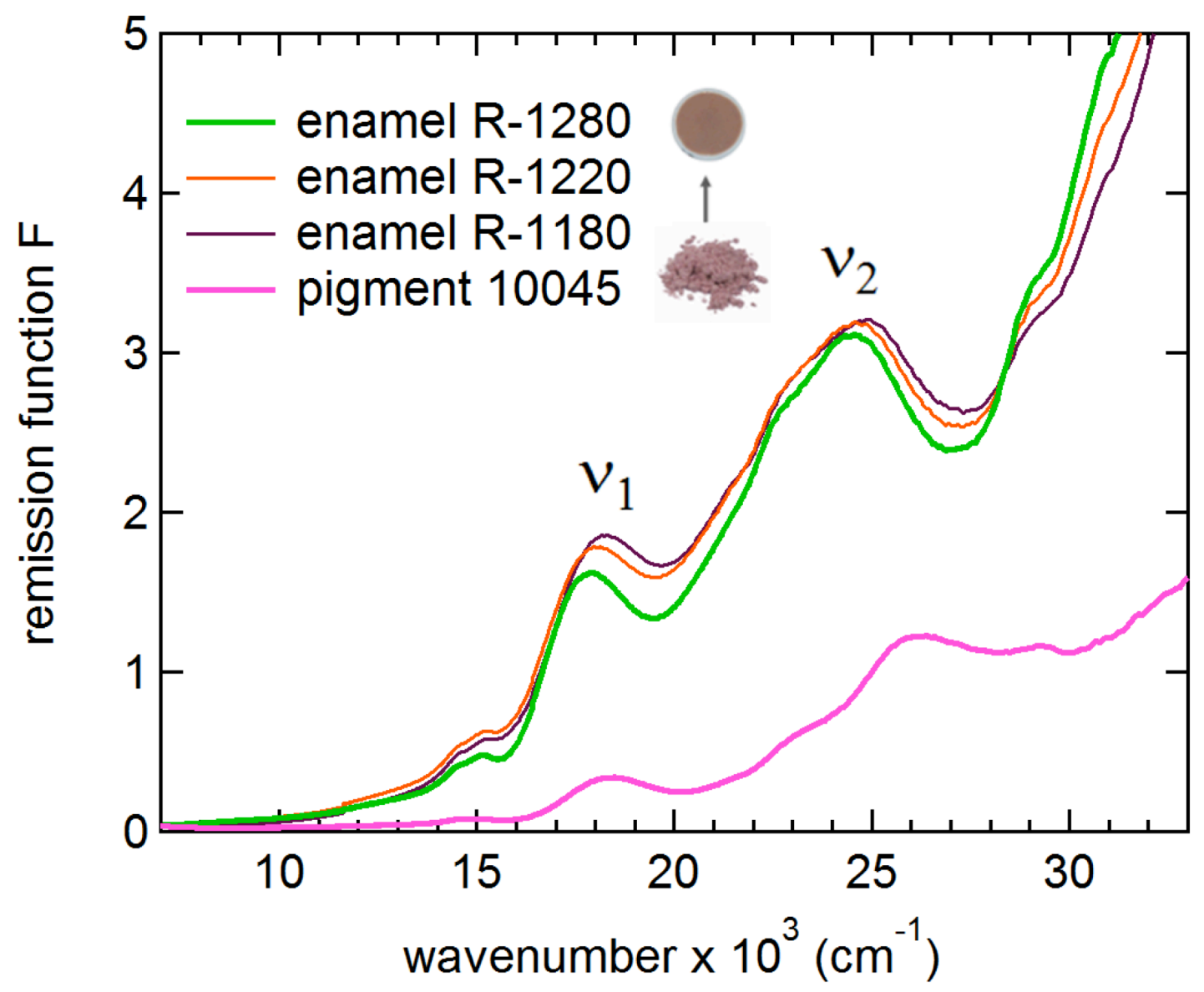

Fig. 3. Remission function $\mathrm{F}\left(\mathrm{Q}_{\infty}\right)$ calculated from the diffuse reflectance spectra of pigment 10045 (pink line) and glazes prepared with this pigment R-1280, R-CIAl1 and R-CIA12. 


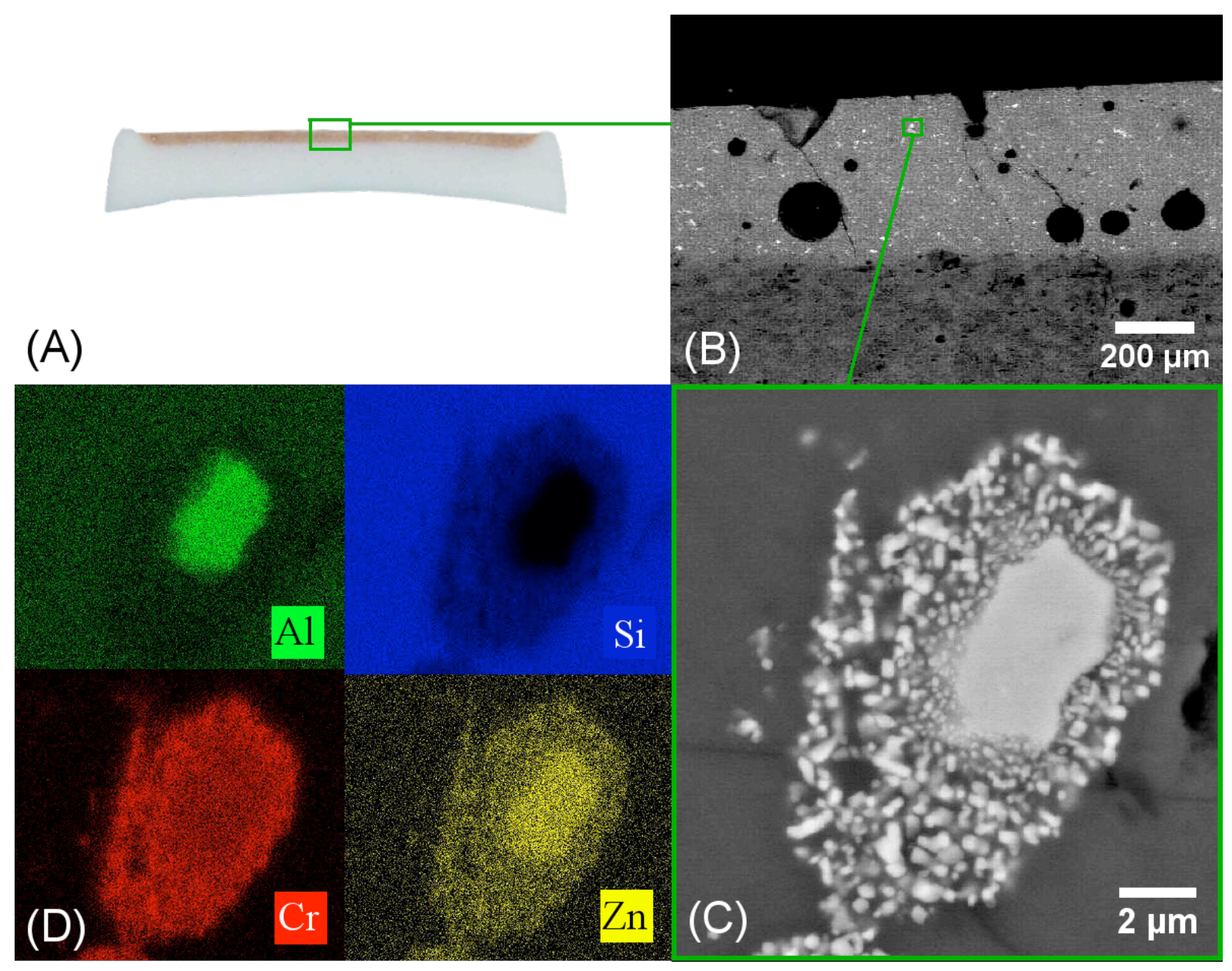

Fig. 4. (A) Picture of a cross-section of sample R-1280; the colored layer corresponds to the glaze and the white part is the porcelain mount; (B) SEM image of the cross-section; (C) Focus on a grain of pigment embedded in the glassy matrix (Signal: ASB, EHT $=15 \mathrm{kV}$ );(D) EDX map of the main elements present in the glaze: Al (green), $\mathrm{Si}$ (blue), $\mathrm{Cr}$ (red) and $\mathrm{Zn}$ (yellow).

Fig. 4(A) and (B) show representative visible and SEM images of a cross section of the glaze obtained after the heat treatment. The glaze is heterogeneous, composed of bubbles and crystallized grains, embedded in a glassy matrix. Fig. $4(\mathrm{C})$ focuses on a specific crystalline grain embedded in the glassy matrix resulting from the melting of the uncolored frit. We observe an interesting difference in morphology between the center of the grain and the 
periphery. The center looks homogeneous while the periphery is fragmented, which corresponds to a difference of chemical composition: indeed, the phase in periphery is richer in $\mathrm{Cr}$ whereas the center of the grain is richer in Al (EDX map in Fig. 4(D)). Some other grains in the glaze are characterized by the same difference of morphology and composition between the center and the periphery. Smaller grains are also present in the glaze, completely fragmented and rich in Cr. SEM observations at different heating treatments allow us to conclude that such crystals are the initial pigment grains, gradually altered by reaction with the frit melt. Furthermore, a glaze composed of pigment 10045 was quenched and the same difference of morphology and composition between the centre and the periphery of grains were observed: it means that the two phases are not resulting from recrystallization during cooling down.

Fig. 5 presents the evolution of the XRD pattern of the glaze after different thermal treatments. We can first observe the formation of a glassy signal with the appearance of a diffuse background near $2 \theta \approx 26^{\circ}$, likely resulting from the melting of the uncolored frit. However, the melting process is not completely achieved since Bragg peaks due to quartz $\mathrm{SiO}_{2}$ are detected up to the highest temperature. The initial phase $\mathrm{ZnAl}_{1.59} \mathrm{Cr}_{0.41} \mathrm{O}_{4}$ gradually disappears in favor of a phase with the same characteristic peaks, but shifted towards lower 20. This corresponds to an increase of the lattice parameter $a$, which is observed when the chromium content $x$ is higher in $\mathrm{ZnAl}_{2-\mathrm{x}} \mathrm{Cr}_{\mathrm{x}} \mathrm{O}_{4}{ }^{9}$ Using equation (1), the composition of the new formed phase is $\mathrm{ZnAl}_{0.54} \mathrm{Cr}_{1.46} \mathrm{O}_{4}$. The peaks of $\mathrm{ZnAl}_{1.59} \mathrm{Cr}_{0.41} \mathrm{O}_{4}$ and $\mathrm{ZnAl}_{0.54} \mathrm{Cr}_{1.46} \mathrm{O}_{4}$ (zoom in Fig. 5) do not shift in position during heating, which indicates a bimodal distribution between the two phases rather than a continuous change in composition. 

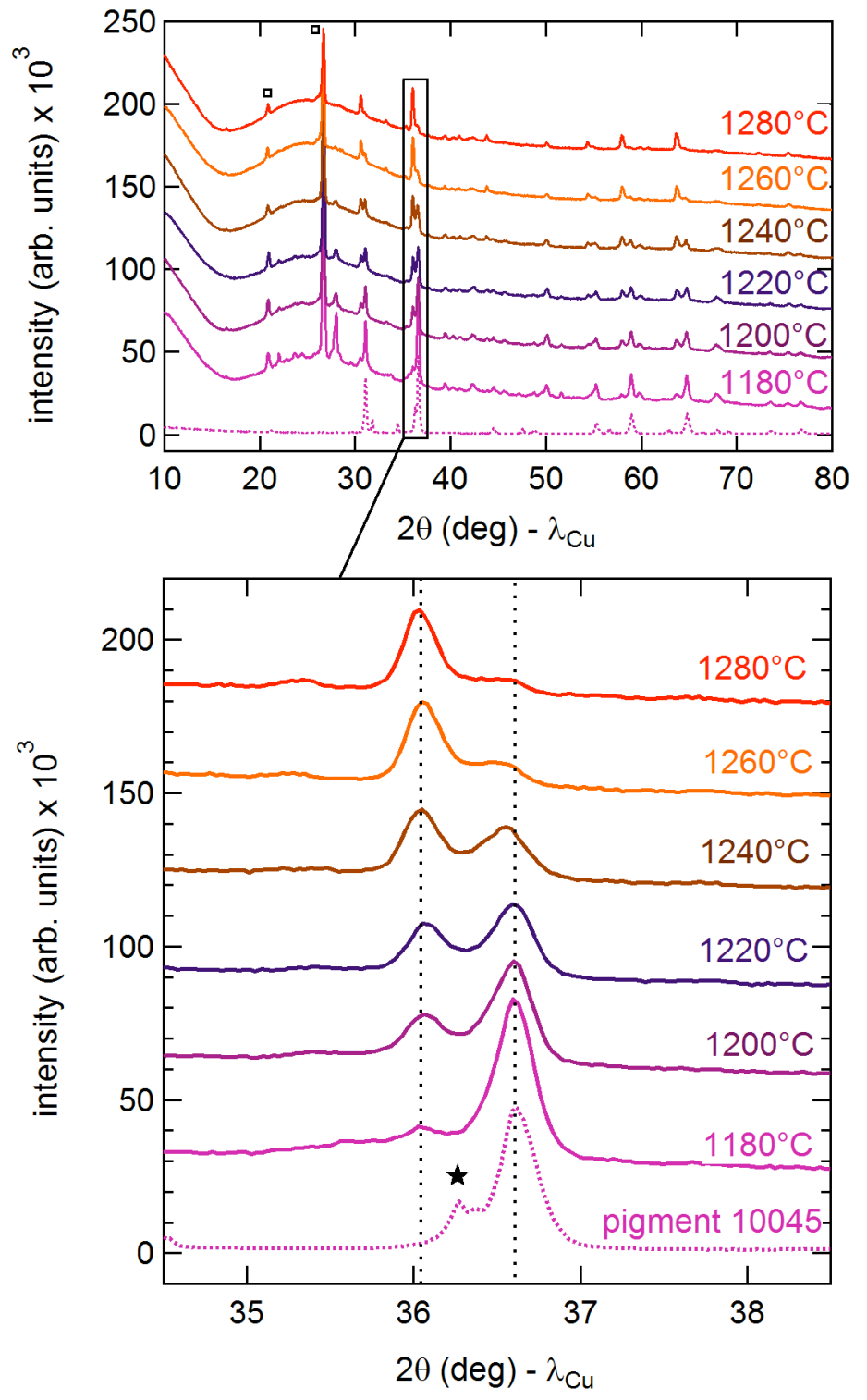

Fig. 5. In solid lines, XRD patterns of the samples fired at different temperatures: R-1180, R1200, R-1220, R-1240, R-1260 and R-1280. In dotted line the initial pigment 10045. Peaks indexed with squares and stars correspond to quartz $\mathrm{SiO}_{2}$ and $\mathrm{ZnO}$.

To determine how $\mathrm{Cr}$ surrounding is changed with the formation of the $\mathrm{Cr}$-rich phase $\mathrm{ZnAl}_{0.54} \mathrm{Cr}_{1.46} \mathrm{O}_{4}$ during firing, $\mu$-XANES analyses at the $\mathrm{Cr}$ K-edge were performed (Fig. 6) to locally probe the chromium environment in the periphery and in the center of the grain. The inset (C) in Fig. 6 is the XRF map acquired on the grain of pigment previously observed 
under SEM. The XANES spectra (Fig. 6(A)) exhibit three features $a, b$ and $c$, which are typical of $\mathrm{Cr}^{3+}$ in octahedral symmetry in spinels. ${ }^{9}$ While the positions of $a$ and $b$ are the same for the two areas, $c$ is shifted by $0.92 \mathrm{eV}$ towards lower energies between the center of the grain and the periphery. The pre-edge region (inset (B) in Fig. 6) shows two features $\alpha$ and $\beta$ common to the two areas and a third feature $\gamma$ only present on the spectra in the periphery of the grain. The shift towards lower energies of the peak $c$ and the appearance of the feature $\gamma$ are observed when the $\mathrm{Cr}$ content increases along the solid solution $\mathrm{ZnAl}_{2-\mathrm{x}} \mathrm{Cr}_{\mathrm{x}} \mathrm{O}_{4}{ }^{{ }^{9}}$

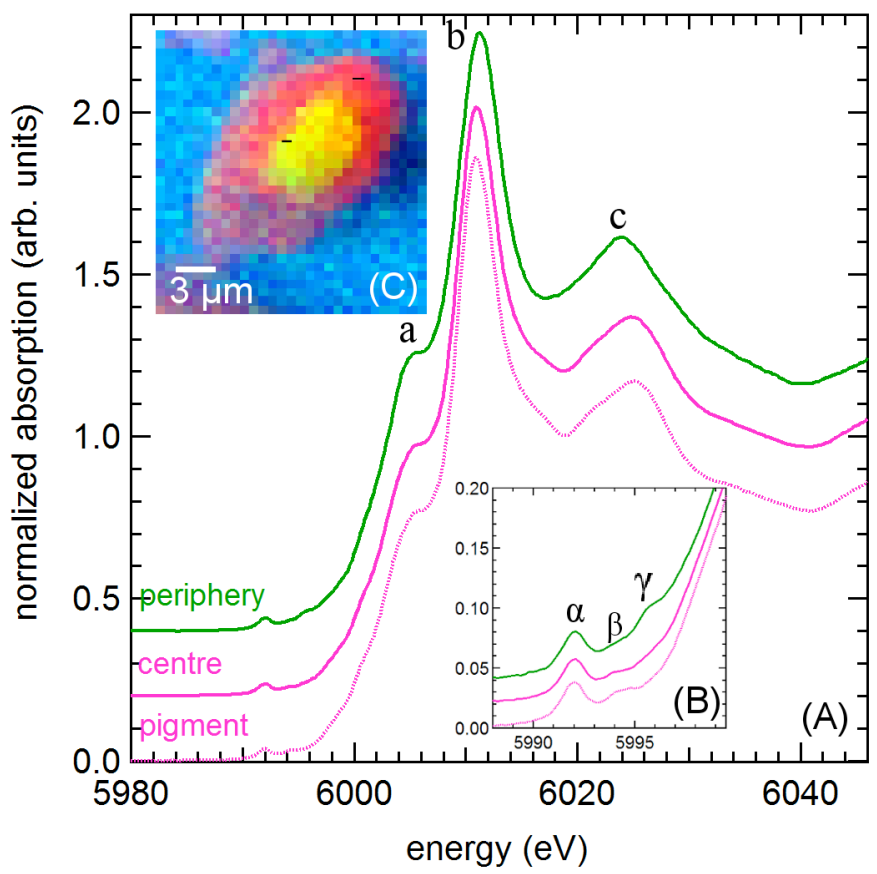

Fig. 6. (A) XANES spectra at the Cr K-edge acquired on the pigment 10045 (dotted line), and on two different areas of the glaze: the centre of the grain of pigment (pink) and the periphery (green). (B) Focus on the pre-edge region. (C) XRF map of the main elements constituting the pigment: Al (green), Si (blue) and $\mathrm{Cr}$ (red). The black dashes represent the areas where the XANES data were acquired and their sizes correspond to the spatial beam size $\left(0.2 \times 0.7 \mu \mathrm{m}^{2}\right)$. 


\section{(3) Influence of the thermal treatment on the stability of Cr-spinel in the glaze}

When wood-fired kilns were used at the manufacture of Sèvres, it was particularly difficult to maintain a constant temperature. The heat ramp was then controlled to be slow enough to fire the porcelain and, once the desired firing temperature was reached, the kiln was turned off. This process is still in use at the manufacture. As the initial pigment is not completely dissolved or transformed in the melt, we decided to change the usual firing process and to test the influence of an isotherm at $1280^{\circ} \mathrm{C}$ with a plateau of 5 hours. XRD and SEM images combined with EDX measurements highlight that the initial grains of pigment totally disappear after the plateau and are replaced by the phase enriched in chromium. Furthermore, isotherms at $1160^{\circ} \mathrm{C}$ and $1200^{\circ} \mathrm{C}$ during 5 hours do not change the composition of the new formed phase. However the process of reaction of the pigment is less advanced when the temperature is lower.

\section{(4) Influence of the initial pigment composition}

The composition of the pigment was modified to investigate the influence of the initial chromium content. Three compositions along the solid solution $\mathrm{ZnAl}_{2-\mathrm{x}} \mathrm{Cr}_{\mathrm{x}} \mathrm{O}_{4}$ were chosen: $x=0.4$, composition closed to the 10045 one, $x=1.4$, which is closed to the phase formed when the pigment 10045 is fired in the glaze, and $x=1.0$, which is an intermediate composition. Using $\mathrm{ZnAl}_{1.6} \mathrm{Cr}_{0.4} \mathrm{O}_{4}$ as a starting reference excludes any potential influence of ZnO. Fig. 7 represents the evolution of the lattice parameter $a$ with the chromium content $x$ in the solid solution $\mathrm{ZnAl}_{2-\mathrm{x}} \mathrm{Cr}_{\mathrm{x}} \mathrm{O}_{4}$ (Fig. 7A) and an example of Rietveld refinement for the sample $\mathrm{ZnAlCrO}_{4}(x=1)$ and its corresponding glaze R-AlCr10 (Fig. 7B). For the composition $x=0.4$, the pigment reacts with the frit to form the phase $\mathrm{ZnAl}_{0.52} \mathrm{Cr}_{1.48} \mathrm{O}_{4}$, which is a composition close to the one obtained from pigment 10045. For the compositions $x=1$ 
and $x=1.4$, a higher chromium enrichment in the final phases is observed: $\mathrm{ZnAl}_{0.32} \mathrm{Cr}_{1.68} \mathrm{O}_{4}$ and $\mathrm{ZnAl}_{0.16} \mathrm{Cr}_{1.84} \mathrm{O}_{4}$, respectively.
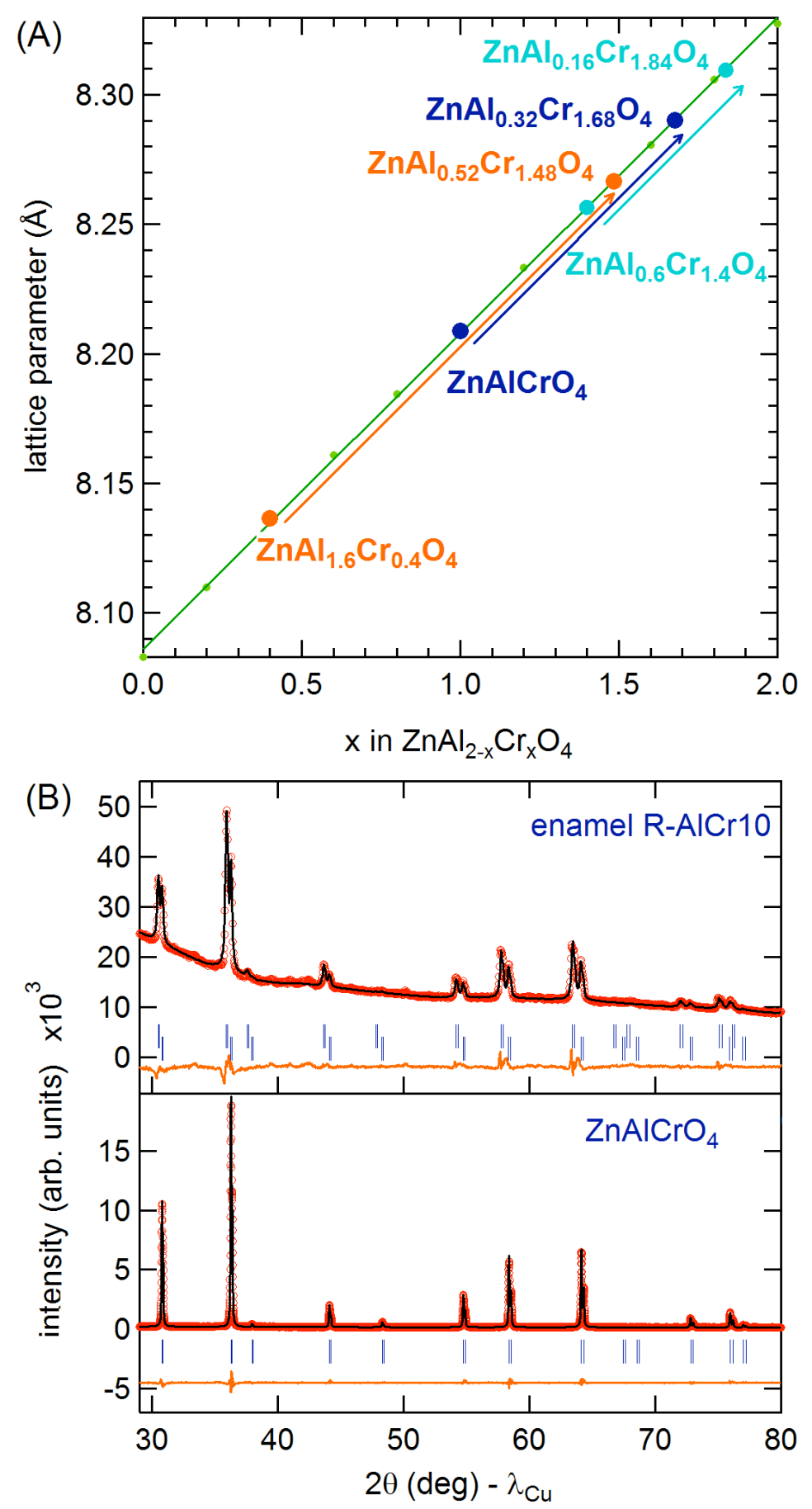

Fig. 7. (A) In green, variation of the cubic lattice parameters $a(\AA)$ of $\mathrm{ZnAl}_{2-\mathrm{x}} \mathrm{Cr}_{\mathrm{x}} \mathrm{O}_{4}$ as a function of Cr concentration $x$ from Verger et $a l . ;^{9}$ the initial compositions of the references 
$\mathrm{ZnAl}_{1.6} \mathrm{Cr}_{0.4} \mathrm{O}_{4}, \mathrm{ZnAlCrO}_{4}$ and $\mathrm{ZnAl}_{0.6} \mathrm{Cr}_{1.4} \mathrm{O}_{4}$ and their evolution in their respective glazes $\mathrm{R}$ $\mathrm{AlCr} 04, \mathrm{R}-\mathrm{AlCr} 10$ and $\mathrm{R}-\mathrm{AlCr} 14$ after the thermal treatment are placed in the diagram. (B) Example of a Rietveld refinement for the reference $\mathrm{ZnAlCrO}_{4}$ and the corresponding glaze RAlCr10 (the same color code is used than in Fig. 2).

There is thus a systematic trend to transform the pigment to a phase richer in $\mathrm{Cr}$ than the initial phase. The chromium content of the final phase strongly depends on the initial pigment composition.

\section{(5) Influence of the uncolored frit composition}

The influence of $\mathrm{Al}$ and $\mathrm{Zn}$ content in the melt on the spinel alteration was investigated, by controlling the composition of the uncolored frit. Since the main difference between uncolored frits from the manufacture of Sèvres regards the Al content, we will not discuss here the influence of $\mathrm{Zn}$.

In a calcium aluminosilicate melt/glass, an important parameter is the charge compensation of the $\mathrm{AlO}_{4}$ tetrahedra by alkali and alkaline-earth cations. The following ratio determines the peraluminosity of the frit:

$R=n_{A l 2 O 3} /\left(n_{\mathrm{Na2O}}+n_{\mathrm{MgO}}+n_{K 2 O}+n_{\mathrm{CaO} O}\right)$

where $n_{\mathrm{Al2O} 3}$ and $\left(n_{\mathrm{Na2O}}+n_{\mathrm{MgO}}+n_{\mathrm{K} 2 \mathrm{O}}+n_{\mathrm{CaO}}\right)$ are the molar contents in alumina and alkali and alkaline-earth oxide in the sample, respectively. When $R<1$, the glass is peralkaline, and when $R>1$, the glass is peraluminous. The peraluminosity of the frit $\mathrm{CI}$ is equal to 0.50 and was increased by adding $\alpha-\mathrm{Al}_{2} \mathrm{O}_{3}$ giving the frits CIAl1 and CIAl2 (Table 2) with $R$ of 0.67 and 0.88 , respectively. Glazes are firstly obtained with the standard treatment $\left(1000^{\circ} \mathrm{C}\right.$ in $10 \mathrm{~h}$ and $1280^{\circ} \mathrm{C}$ in $5.5 \mathrm{~h}$ ). The pink color of the Al-rich glazes (CIAl1 and CIAl2) appears 
preserved after the thermal treatment. Fig. 3 shows the remission function $F\left(\varrho_{\infty}\right)$ of the initial pigment 10045 and the glazes obtained from the different frits. The positions of the two main absorption bands of R-CIA11 and R-CIA12 glazes are shifted towards lower wavenumbers compared to the pigment, but they are less shifted than R-1280.

This result is confirmed by SEM observations. Fig. 8 shows grains of pigment in R-CIAl1 and R-CIA12. Reaction layers between the grains of pigment and the frit are smaller than the one observed for the R-1280 glaze (Fig. 4). This has been observed over many grains of pigments and is representative of the sample.

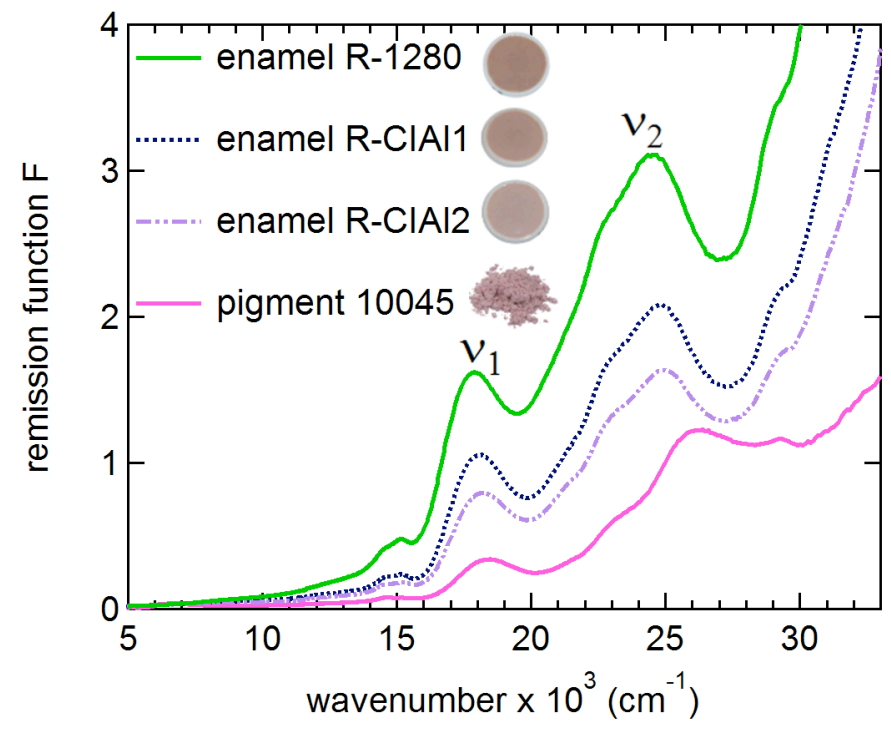

Fig. 8. SEM images of a grain of pigment from the glazes R-CIAl1 (left) and R-CIAl2 (right).

After the standard heating treatment, R-CIAl1 and R-CIAl2 are only partially melted because the addition of $\mathrm{Al}_{2} \mathrm{O}_{3}$ reduces fusiblity of the mixture. The presence of phases remaining from CIAl1 and CIA12 makes Rietveld refinements more complex. Therefore, the temperature of firing was increased to $1350^{\circ} \mathrm{C}$ and a plateau of $10 \mathrm{~h}$ was applied to fully vitrify the frits. Fig. 9 presents the XRD diagrams for the three glazes fired with this new thermal treatment. 
We observe that when the $\mathrm{Al}$ content increases in the frit, the new phase formed has a higher $\mathrm{Al}$ content, indicating that $\mathrm{Al}$ migrates less in the glass.

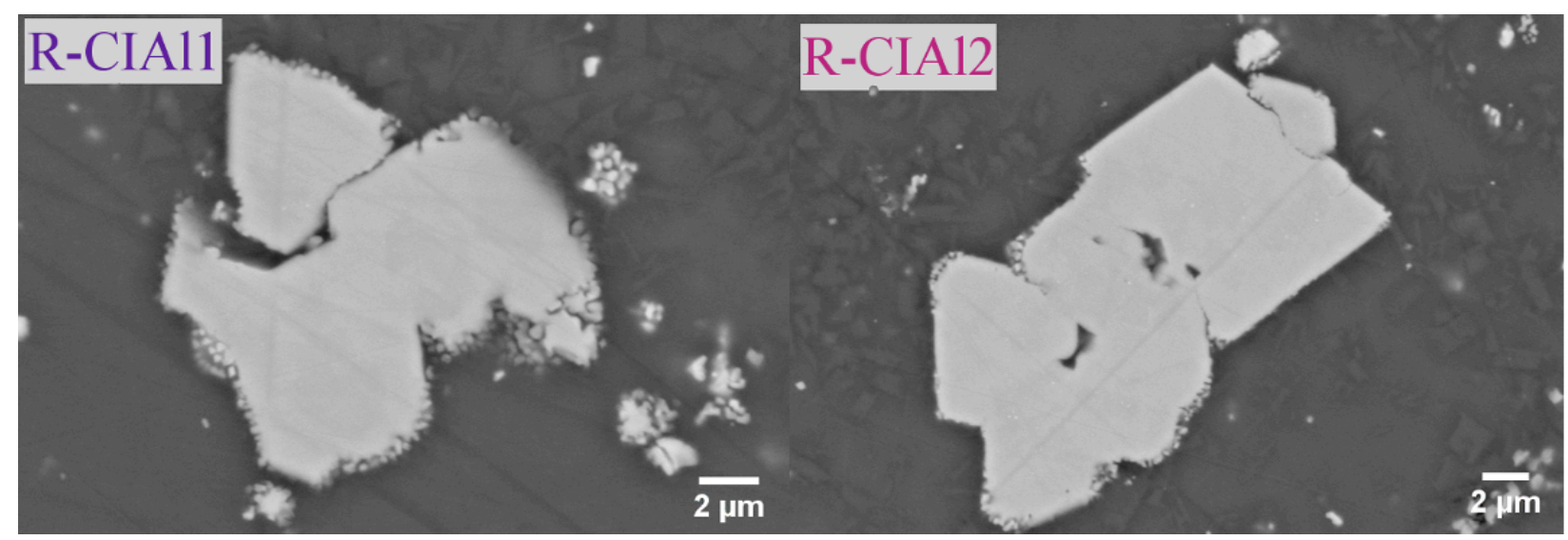

Fig. 9. (A) In green, variation of the cubic lattice parameters $a(\AA)$ of $\mathrm{ZnAl}_{2-\mathrm{x}} \mathrm{Cr}_{\mathrm{xO} 4}$ as a function of $\mathrm{Cr}$ concentration $x$ from Verger et al. ${ }^{9}$ the initial composition of the pigment 10045 and its evolution in the uncolored frits CI (green), CIAl1 (purple) and CIA12 (pink) after the thermal treatment are placed in the diagram. (B) XRD patterns of the samples R1350-10h, R-CIAl1-1380-10h and R-CIAl2-1350-10h between $30^{\circ}$ and $70^{\circ} 2 \theta$.

\section{Discussion}

\section{(1) Relationship between pigment stability and the color of glazes}

A reaction occurs between the grains of pigment and the silicate melt during firing of the glaze. It results in the formation of a Cr-enriched gahnite, belonging to the solid solution $\mathrm{ZnAl}_{2-\mathrm{x}} \mathrm{Cr}_{\mathrm{x}} \mathrm{O}_{4}$ as the initial pigment. The modification of composition from $\mathrm{x}=0.41$ (pink) to $\mathrm{x}=1.46$ (brownish) explains the change of color between the pigment and the glaze after firing due to a change of the crystal field around $\mathrm{Cr}^{3+}$ ions. As explained previously, ${ }^{9}$ at high $\mathrm{Cr}$ content, the presence of other $\mathrm{Cr}^{3+}$ neighbors in the second shell of a $\mathrm{Cr}^{3+}$ ion generates an electronic potential that affects the $\mathrm{e}_{g}$ and $\mathrm{t}_{2 g}$ orbitals separation or the orbital mixing between 
the $\mathrm{Cr} d$ states and the neighboring $\mathrm{O} p$ states. These changes in the $\mathrm{Cr}$ environment are at the origin of the color modification. Therefore, the color change results from a modification of the $\mathrm{Cr}$ content in the spinel structure, without modification of $\mathrm{Cr}$ valency or the crystalline structure. Since there is no source of $\mathrm{Cr}$ in the system, the $\mathrm{Cr}$-enrichment of the spinel phase results from the decrease of $\mathrm{Al}$ and $\mathrm{Zn}$ contents, with both elements migrating towards the melt. This process can be summarized by the following equation:

$$
\left[\mathrm{ZnAl}_{2-x} \mathrm{Cr}_{x} \mathrm{O}_{4}\right]_{\text {crystal }} \rightarrow x / y\left[\mathrm{ZnAl}_{2-y} \mathrm{Cr}_{y} \mathrm{O}_{4}\right]_{\text {crystal }}+(1-x / y)\left[\mathrm{ZnAl}_{2} \mathrm{O}_{4}\right]_{\text {glass }}
$$

where $x=0.41$ et $y=1.46$ with experimental conditions used in part III.(2) (temperature of firing and chemical composition of $\mathrm{CI}$ ). Al migration towards the silicate melt is driven by the low peraluminosity of the frit and therefore by the amount of free alkali or alkaline-earth cations in the melt.

The color alteration found here has a different mechanism compared to previous studies investigating the stability of corundum-like pigment in $\mathrm{ZnO}$-rich frit. ${ }^{14,15}$ Indeed, corundum type pigment $(\mathrm{Fe}, \mathrm{Cr})_{2} \mathrm{O}_{3}$ forms a reaction layer composed of spinel $(\mathrm{Zn}, \mathrm{Fe})(\mathrm{Cr}, \mathrm{Fe})_{2} \mathrm{O}_{4}$ and, in this case, the color change is due to a Fe valency modification from $\mathrm{Fe}^{3+}$ to $\mathrm{Fe}^{2+}$ and results from the spinel crystallization and Fe diffusion in the glaze.

Other pigments used at Sèvres, which are composed of spinels, were studied with the same approach: pigment 10024 composed of $\mathrm{MgAl}_{2-\mathrm{x}} \mathrm{Cr}_{\mathrm{x}} \mathrm{O}_{4}$ and pigment 10014 composed of $\mathrm{Co}_{1-\mathrm{y}} \mathrm{Mg}_{\mathrm{y}} \mathrm{Al}_{2-\mathrm{x}} \mathrm{Cr}_{\mathrm{x}} \mathrm{O}_{4}$. Both systems react in the same way in the frit CI: gradual dissolution of the initial pigment leading to a Cr-enriched phase and therefore a color change. At the manufacture of Sèvres, almost $60 \%$ of pigments containing chromium oxides are spinel-type. However, they are not used for the porcelain decoration described in this article using the uncolored frit CI. Our study shows that stabilizing the Cr-doped spinel structure appears challenging due to the low peraluminosity of glass/melt, resulting in a poor control of the final 
glaze coloration. A way to stabilize Cr-doped gahnite is to increase the peraluminosity of the frit. However, this requires an increase of the firing temperature to obtain a glassy aspect for the glaze. Another possibility is to crystallize Cr-doped gahnite during firing of the glaze. This can be achieved by adding $\mathrm{ZnO}$ in the frit $\mathrm{CI}$, and by using an initial pigment composed of $\mathrm{Al}_{2-\mathrm{x}} \mathrm{Cr}_{\mathrm{x}} \mathrm{O}_{3}$ instead of $\mathrm{ZnAl}_{2-\mathrm{x}} \mathrm{Cr}_{\mathrm{x}} \mathrm{O}_{4}$, in a similar way as observed by Martos et al. ${ }^{13}$

\section{(2) The role of $\mathrm{Cr}$, Al and $\mathrm{Zn}$ in the dissolution of spinel in glass melt}

Our study shows that the initial pigment is strongly altered by the aluminosilicate melt formed from the uncoloured frit. This partial dissolution at $1280^{\circ} \mathrm{C}$ results in $\mathrm{Cr}$-rich spinel that are even less stable at high temperature such as $1380^{\circ} \mathrm{C}$, as $\mathrm{Cr}$ is likely to diffuse in the melt. We did not look at the Cr diffusing in the glass because its quantity is very small and is unlikely to modify the color of the glaze. A complete study, beyond the scope of this article, of the solubility of spinel belonging to the system $\mathrm{ZnAl}_{2-\mathrm{x}} \mathrm{Cr}_{\mathrm{x}} \mathrm{O}_{4}$ in glass melt controlling the temperature and the oxygen fugacity would be interesting to understand better the physicochemical properties of $\mathrm{Cr}$ in melts..$^{22-24}$

$\mathrm{Al}$ and $\mathrm{Zn}$ play a key role in this dissolution process. By controlling the $\mathrm{Al}$ proportion in the uncolored frit, the $\mathrm{Cr}$ content $x$ or $\mathrm{Cr} /(\mathrm{Cr}+\mathrm{Al})$ is modified in the resulting spinel phase. It is then possible to stabilize the spinel phase in the uncolored frit. Roeder et al. showed that the $\mathrm{Al}_{2} \mathrm{O}_{3}$ content in the melt correlates well with the quantity $\mathrm{Cr} /(\mathrm{Cr}+\mathrm{Al})$ found in the spinel phase..$^{25}$ Even if the mechanism is not the same (crystallization of spinel or reentrant magmas in the article by Roeder et al. ${ }^{25}$ and dissolution of spinel in our case), both are driven by the quantity of $\mathrm{Al}_{2} \mathrm{O}_{3}$ in the melt. This explains why pigments composed of gahnite $\left(\mathrm{ZnAl}_{2} \mathrm{O}_{4}\right)$ doped with $\mathrm{Cr}$ are usually used at the Manufacture on glaze fired at $1380^{\circ} \mathrm{C}$, solely: the 
uncolored frit used at this temperature is richer in $\mathrm{Al}$ than the one fired at $1280^{\circ} \mathrm{C}$ and thus the initial pink color of the pigment is preserved.

\section{V.Conclusions}

At the manufacture of Sèvres, a pink pigment mainly composed of the spinel phase $\mathrm{ZnAl}_{1.59} \mathrm{Cr}_{0.41} \mathrm{O}_{4}$ has been synthesized for more than a century. Used in a particular composition of uncolored frit to obtain a glaze, an undesired brown color appears. We showed that the initial pigment reacts during firing: it gradually dissolves in favor of a phase richer in chromium $\mathrm{ZnAl}_{0.54} \mathrm{Cr}_{1.46} \mathrm{O}_{4}$, responsible for the color change. We also showed that the composition of the final phase depends on (i) the composition of the initial spinel phase and (ii) the composition of the uncolored frit, in particular the $\mathrm{Al}_{2} \mathrm{O}_{3}$ content. Alteration of the pigment occurs despites modification of the temperature of firing of the glaze and the initial $\mathrm{Cr}$ content. The stability of the spinel phase is driven by the amount of $\mathrm{Al}$ in the uncolored frit. This study brings useful information on the particular role of $\mathrm{Al}, \mathrm{Cr}$ and $\mathrm{Zn}$ in spinel stability in melts. The reactivity (dissolution or crystallization) of minerals in silicate melts gathers interest for geologists (formation of minerals in magmas), ${ }^{26-30}$ chemists (corrosion of materials by molten glasses) $)^{22}$ and in the optoelectronic field (controlled crystallization of nano particles in glass)..$^{31-33}$

\section{Acknowledgement}

This work was supported by the Réseau Francilien sur les oxydes fonctionnels (DIM Oxymore) and the Région Ile-de-France. We acknowledge the European Synchrotron Radiation Facility for provision of synchrotron radiation facilities at beamline ID21, through the proposal HG43. L. Verger acknowledges C. Bouttaz for her expertise in the preparation of the 
samples. The purchase of the Scanning Electron Microscope (SEM) facility of the IMPMC was supported by Région Ile de France grant SESAME 2006 NI-07-593/R, INSU-CNRS, INP-CNRS, University Pierre et Marie Curie - Paris 6, and by the French National Research Agency (ANR) grant no. ANR-07-BLAN-0124-01.

\section{References}

[1] A. Doménech, F. J. Torres, E. Ruiz de Sola, and J. Alarcon, "Electrochemical Detection of High Oxidation States of Chromium(IV andV) in Chromium-Doped Cassiterite and TinSphene Ceramic Pigmenting Systems," European Journal of Inorganic Chemistry, 2006[3] 638-648 (2006).

[2] E. Lopez-Navarrete, A. Caballero, V. M. Orera, F. J. Lazaro, and M. Ocaña, “Oxidation state and localization of chromium ions in Cr-doped cassiterite and Cr-doped malayaite," Acta Materialia, 51[8] 2371-2381 (2003).

[3] E. Cordoncillo, F. del Rio, J. Carda, M. Llusar, and P. Escribano, "Influence of some mineralizers in the synthesis of sphene-pink pigments," Journal of the European Ceramic Society, 18[8] 1115-1120 (1998).

[4] F. J. Berry, N. Costantini, and L. E. Smart, "Synthesis of chromium-containing pigments from chromium recovered from leather waste," Waste Management, 22[7] 761-772 (2002).

[5] F. Andreola, L. Barbieri, F. Bondioli, M. Cannio, A.M. Ferrari, and I. Lancellotti, "Synthesis of chromium containing pigments from chromium galvanic sludges," Journal of Hazardous Materials, 156[1-3] 466-471 (2008).

[6] S.R. Prim, A. Garciaa, R. Galindo, S. Cerro, M. Llusar, M.V. Folgueras, and G. Monros, "Pink ceramic pigments based on chromium doped $\mathrm{M}\left(\mathrm{Al}_{2-\mathrm{x}} \mathrm{Cr}_{\mathrm{x}}\right) \mathrm{O}_{4}, \mathrm{M}=\mathrm{Mg}, \mathrm{Zn}$, normal spinel," Ceramics International, 39[6] 6981-6989 (2013). 
[7] U. Halenius, G. B. Andreozzi, and H. Skogby, "Structural relaxation around $\mathrm{Cr}^{3+}$ and the red-green color change in the spinel (sensu stricto)-magnesiochromite $\left(\mathrm{MgAl}_{2} \mathrm{O}_{4}-\mathrm{MgCr}_{2} \mathrm{O}_{4}\right)$ and gahnite-zincochromite $\left(\mathrm{ZnAl}_{2} \mathrm{O}_{4}-\mathrm{ZnCr}_{2} \mathrm{O}_{4}\right)$ solid-solution series," American Mineralogist, 95[4] 456-462 (2010).

[8] F. Bosi, G. B. Andreozzi, U. Halenius, and H. Skogby, "Zn-O tetrahedral bond length variations in normal spinel oxides," American Mineralogist, 96[4] 594-598 (2011).

[9] L. Verger, O. Dargaud, G. Rousse, E. Rozsalyi, A. Juhin, D. Cabaret, M. Cotte, P. Glatzel, and L. Cormier, "Spectroscopic properties of $\mathrm{Cr}^{3+}$ in the spinel solid solution $\mathrm{ZnAl}_{2-\mathrm{x}} \mathrm{Cr}_{\mathrm{x}} \mathrm{O}_{4}$," Physics and Chemistry of Minerals, 43[1] 33-42 (2016).

[10] A. D’Albis, “Traité de la Porcelaine de Sèvres,” Editions Faton (2003).

[11] S. H. Murdock and R. A. Eppler, "The interaction of ceramic pigments with glazes," American Ceramic Society Bulletin, 68[1] 77-78 (1989).

[12] D. R Eppler and R. A. Eppler, "The relative stability of ceramic pigments," Ceramic Engineering and Science Proceedings, 18[2] 139 -149 (1997).

[13] M. Martos, M. Martínez, E. Cordoncillo, and P. Escribano, “Towards more ecological ceramic pigments: Study of the influence of glass composition on the colour stability of a pink chromium-doped ceramic pigment," Journal of the European Ceramic Society, 27[16] 4561-4567 (2007).

[14] E. Ozel and S. Turan, "Production and characterisation of iron-chromium pigments and their interactions with transparent glazes," Journal of the European Ceramic Society, 23[12] 2097-2104 (2003).

[15] H. Yurdakul, S. Turan, and E. Ozel, "The mechanism for the color change of iron chromium black pigments in glazes through transmission electron microscopy techniques," Dyes and Pigments, 91[2] 126-133 (2011). 
[16] H. M. Rietveld, “A profile refinement method for nuclear and magnetic structures," Journal of Applied Crystallography, 2[2] 65-71 (1969).

[17] J. Rodriguez-Carvajal, "Recent advances in magnetic structure determination by neutron powder diffraction," Physica B: Condensed Matter, 192[1-2] 55-69 (1993).

[18] P. Kubelka and F. Munk, "Ein Beitrag zur Optik der Farbanstriche," Z. Tech. Phys., 12, 593-601 (1931).

[19] V.A. Solé, E. Papillon, M. Cotte, Ph. Walter, and J. Susini, “A multiplatform code for the analysis of energy-dispersive X-ray fluorescence spectra," Spectrochimica Acta Part B: Atomic Spectroscopy, 62[1] 63-68 (2007).

[20] D. L. Wood, "Optical Spectrum of $\mathrm{Cr}^{3+}$ Ions in Spinels," The Journal of Chemical Physics, 48[11] 5255-5263 (1968).

[21] K. Ikeda, Y. Nakamura, K. Masumoto, and H. Shima, "Optical spectra of synthetic spinels in the system $\mathrm{MgAl}_{2} \mathrm{O}_{4}-\mathrm{MgCr}_{2} \mathrm{O}_{4}$," Journal of the American Ceramic Society, 80[10] 2672-2676 (1997).

[22] H. Khedim, R. Podor, C. Rapin, and M. Vilasi, "Redox-Control Solubility of Chromium Oxide in Soda-Silicate Melts," Journal of the American Ceramic Society, 91[11] 3571-3579 (2008).

[23] H. Khedim, R. Podor, P. J. Panteix, C. Rapin, and M. Vilasi, "Solubility of chromium oxide in binary soda-silicate melts," Journal of Non-Crystalline Solids, 356[50-51] 2734$2741(2010)$.

[24] H. Khedim, S. Abdelouhab, R. Podor, C. Rapin, M. Vilasi, P.-J. Panteix, M. Toplis, and F. Faure, "Kinetic and equilibrium factors affecting saturation of chromium oxide in sodasilicate melts," Journal of Non-Crystalline Solids, 357[1] 31-42 (2011). 
[25] P. L. Roeder and I. Reynolds, "Crystallization of Chromite and Chromium Solubility in Basaltic Melts," Journal of Petrology, 32[5] 909-934 (1991).

[26] T. N. Irvine, "Chromian spinel as a petrogenetic indicator: Part 1. Theory," Canadian Journal of Earth Sciences, 2[6] 648-672 (1965).

[27] T. N. Irvine, "Chromian spinel as a petrogenetic indicator: Part 2. Petrologic Applications," Canadian Journal of Earth Sciences, 4[1] 71-103 (1967).

[28] D. Lenaz and F. Princivalle, "The crystal chemistry of detrital chromian spinel from the southeastern alps and outer dinarides: the discrimination of supplies from areas of similar tectonic setting?," The Canadian Mineralogist, 43[4] 1305-1314 (2005).

[29] S. J. Barnes and P.L. Roeder, "The Range of Spinel Compositions in Terrestrial Mafic and Ultramafic Rocks," Journal of Petrology, 42[12] 2279-2302 (2001).

[30] C. Perinelli, F. Bosi, G. B. Andreozzi, A. M. Conte, and P. Armienti, "Geothermometric study of Cr-spinels of peridotite mantle xenoliths from northern Victoria Land (Antarctica)," American Mineralogist, 99[4] 839-846 (2014).

[31] F. Rossi, G. Pucker, M. Montagna, M. Ferrari, and A. Boukenter, "Fluorescence line narrowing study of $\mathrm{Cr}^{3+}$ ions in cordierite glass nucleating $\mathrm{MgAl}_{2} \mathrm{O}_{4}$ nanocrystals," Optical Materials, 13[4] 373-379 (2000).

[32] Cz. Koepke, K. Wisniewski, M. Grinberg, and G. H. Beall, "Excited state absorption in the gahnite glass ceramics and its parent glass doped with chromium", Spectrochimica Acta Part A: Molecular and Biomolecular Spectroscopy, 54[11] 1725-1734 (1998).

[33] K.A. Subbotin, V.A. Smirnov, E.V. Zharikov, L.D. Iskhakova, V.G. Senin, V.V. Voronov, and I.A. Shcherbakov, "Nano-glass-ceramics containing chromium-doped $\mathrm{LiGaSiO}_{4}$ crystalline phases," Optical Materials, 32[9] 896-902 (2010). 